\title{
Identification of Farmer Priorities in Potato Production Through Participatory Variety Selection
}

\author{
Semagn Asredie Kolech ${ }^{1,3}$ • Donald Halseth ${ }^{1} \cdot$ Keith Perry $^{1}$ • Walter De Jong ${ }^{1}$ • \\ Fentahun Mengistu Tiruneh ${ }^{2}$ - David Wolfe ${ }^{1}$
}

Published online: 5 November 2015

(C) The Author(s) 2015. This article is published with open access at Springerlink.com

\begin{abstract}
A substantial number of farmers in northwest Ethiopia grow potato in the dry season ("Belmehr", March to August) when rainfall is not dependable for the growth of the crop, resulting in lower yield. Ethiopian Agricultural Research Institutes have tried to change the situation by releasing new late blight tolerant varieties that potentially could allow for production of the crop in the rainy season ("Meher", May to October). Despite these efforts, the majority of the farmers still grow potato in the Belmehr season using older, local varieties. Cognizant of this fact, this study aimed to characterize the major potato production problems in the two seasons, to identify the traits that farmers consider most important when selecting potato varieties, and to assess the performance of widely grown local as well as newly developed varieties. The study was conducted at sites representing two major agroecological zones in northwest Ethiopia and during both production seasons using 12 varieties (9 local and 3 new) with a 'participatory variety selection' approach. During the Belmehr season, erratic rainfall resulted in low yield and lower average tuber weight. By contrast, in the Meher season, late blight, desiccating wind and severe precipitation, including hail, limited production. These factors were important in both agroecological zones, with varying degrees of importance. Twenty-three traits were found to influence the varieties that
\end{abstract}

Semagn Asredie Kolech

sk2564@cornell.edu

1 School of Integrative Plant Science, Cornell University, Ithaca, NY, USA

2 Ethiopian Institute of Agricultural Research (EIAR), Addis Ababa, Ethiopia

3 Amhara Agricultural Research Institute (ARARI), Bahir Dar, Ethiopia farmers selected, with the degree of importance of each trait differing between agroecological zones and gender groups. Some local varieties yielded as well as new varieties in both seasons. Overall, we found participatory variety selection to be an effective approach for identifying factors important for the adoption of potato varieties, including factors that may not be addressed in conventional potato breeding programs.

Resumen Un número substancial de agricultores en el noroeste de Etiopía cultivan papa en la época seca ("Belmehr", marzo a agosto) cuando no se depende de la lluvia para el crecimiento del cultivo, lo que resulta en rendimiento más bajo. Los Institutos de Investigación Agrícola de Etiopía han intentado cambiar la situación mediante la liberación de nuevas variedades tolerantes al tizón tardío que pudieran permitir potencialmente la producción del cultivo en la época de lluvias ("Meher", mayo a octubre). A pesar de estos esfuerzos, la mayoría de los agricultores aún cultivan papa en la temporada Belmehr usando variedades más viejas, locales. En conocimiento de este hecho, este estudio tuvo como propósito la caracterización de los principales problemas en la producción de papa en las dos épocas, para identificar los rasgos que los productores consideren como los más importantes cuando estén seleccionando variedades de papa, y analizar el comportamiento de variedades locales ampliamente cultivadas, así como las recientemente desarrolladas. Se condujo el estudio en sitios que representaran dos zonas agroecológicas mayores en el noroeste de Etiopía y durante ambas temporadas de producción, usando 12 variedades (9 locales y 3 nuevas) con un enfoque de "selección participativa de variedades". Durante el ciclo Belmehr, la lluvia errática dio como resultado bajo rendimiento y un promedio de peso de tubérculo más bajo. En contraste, en el ciclo Meher, el tizón tardío, el viento 
deshidratador y precipitación severa, incluyendo granizo, limitaron la producción. Estos factores fueron importantes en ambas zonas agroecológicas, con diversos niveles de importancia. Se encontraron 23 características que influenciaron las variedades que seleccionaron los productores, con el grado de importancia de cada característica difiriendo entre las zonas agroecológicas y grupos de género. Algunas variedades locales rindieron tan bien como las nuevas en ambos ciclos. En general, encontramos que la selección de variedades participativa fue un enfoque efectivo en la identificación de factores importantes para la adopción de variedades de papa, incluyendo aspectos que pudieran no estar considerados en programas convencionales de mejoramiento de papa.

Keywords Ethiopia - Growing seasons · Agroecological zones $\cdot$ Gender $\cdot$ Variety $\cdot$ Variety traits

\section{Introduction}

Potato (Solanum tuberosum L.) is an important food security crop in Ethiopia that is grown in widely differing agroecological zones and growing seasons. The country has four distinct seasons (Belg, Meher, Belmehr and Mesino) for production and these have been described by a number of workers (Gebremedhin et al. 2008; Agajie et al. 2008; Yazie et al. 2009; Gildemacher et al. 2009a; Kolech et al. 2015). There is some confusion in the literature about seasons of potato production due to a lack of distinction between the Belmehr and Meher seasons (Kolech et al. 2015). The descriptions of each season are as follows.

The Belg season, also called the short rainy season, starts in January and continues to May or June. This season is commonly used for potato production in Oromia (East and West Arsi), in the Southern Nations, Nationalities and Peoples' State (SNNP) and in some areas of central Ethiopia. Late blight pressure is less problematic in the Belg season because of relatively low rainfall and humidity (Bekele and Eshetu 2008). Moreover, Belg is a favorable season for farmers to get good market prices because of a cultural factor; this season coincides with a fasting period where participants avoid meat and milk products.

The Meher season, also called the rainy season, starts in May or June and ends in October. Late blight is the major potato production challenge in this season and losses to late blight are thought to be responsible for some farmers shifting production to the Belg season (Bekele and Eshetu 2008). Potato production in Meher is common in Shashemene and surrounding areas (Agajie et al. 2008; Kolech et al. 2015). Ethiopian Research Institutes are working to expand potato production into the Meher season by developing late blight resistant and early maturing varieties.
The Belmehr season overlaps the Belg and the Meher seasons. Belmehr potato production starts in March or April and lasts into August. Most potato production in northwest Ethiopia takes place during Belmehr. Potato is the only crop grown during this season and it is a primary source of food for residents of the highland during July and August, filling a critical gap. Starting in the middle of this season, farmers in the northwest start to sow other crops under the potato crop.

The Mesino season, also called the residual production season, starts in September and continues through December or January. It is a cropping season for residual potato and barley production immediately following the main rainy season. Some farmers in the moist agroecological zone of northwest Ethiopia grow potato in this season, however, yield is very low (Yazie et al. 2009; Kolech et al. 2015).

Unlike other major crops, most potato production (more than $62 \%$ of $179,000 \mathrm{ha}$ ) takes place during Belg and Belmehr seasons (CSA 2014). The productivity in these seasons is reportedly very low, only 7.3 ton/ha, as the moisture conditions are inadequate, especially in the Belmehr season. Different reasons have been suggested as to why farmers grow potato in the Belmehr season despite the known challenges and lower yields. One is related to filling the gap in food availability during the "hungry months" of July and August (Gebremedhin et al. 2008; Gebremedhin 2013). Another reason to grow during this season is to avoid the late blight damage seen in the main (rainy) season (Bekele and Eshetu 2008; Gebremedhin et al. 2008). A third reason is a lack of seed of well-adapted, late blight-resistant varieties for production during the main season.

The Ethiopian agricultural research system, including federal and regional research institutes as well as universities, has allocated considerable resources to the development and dissemination of improved potato varieties to increase potato production and productivity by small farmers. The variety improvement program utilizes germplasm sourced mainly from the International Potato Center (CIP) (Gebremedhin et al. 2008) and focuses selection on yield potential and late blight resistance. Since 1975, the Ethiopian agricultural research institutes, Haramaya University and one private seed company (SolaGrow) have developed 31 potato varieties (MOA 2013), mainly for production in the Meher season. Potato production has increased during the Meher season as a result of these varieties, especially in the areas of Guraghe, West Shewa and North Shewa (Kolech et al. 2015). Success has been especially good in areas where potato production only began recently.

Although the improved varieties have been reported to be high yielding and resistant to late blight, their adoption by farmers has been low in most areas where the new varieties have been disseminated (Abebe et al. 2013; Gebremedhin 2013). As a result, only a few of the new varieties are grown (Gebremedhin 2013). Hence, the 
majority of smallholder farmers still grow their own local potato varieties (Gildemacher et al. 2009b; Hirpa et al. 2010) and most farmers in northwest Ethiopia still grow potato in the dry season (CSA 2014).

Three overlapping factors may account for the limited adoption of new varieties. The first is that there may be a mismatch between the goals of potato breeders and the needs and preferences of farmers. Farmers need multiple traits in their potatoes to fulfill multiple needs, and they may not adopt a new variety that performs well for some traits but poorly for others (Bellon 2002). A second factor pertains to subjective traits such as taste, culinary quality, and color. Recognizing and breeding for subjective traits is a difficult challenge for breeders operating without close collaboration with farmers and social scientists (Almekinders and Elings 2001; Bellon 2002). A third factor is related to storability, which varies between varieties, environments and agronomic practices. It is difficult for breeders to evaluate storage properties for so many possible conditions.

An additional concern is that local varieties are thought to have low yield potential and to be susceptible to late blight (Kidane-Mariam 1980; Lemaga 1983). Because of this, local varieties have received little attention in potato breeding efforts in Ethiopia. There has, however, never been an experimental confirmation of the low yield of local varieties when starting with disease-free seed. Yield trials in Ethiopia often include local varieties as a check when evaluating new germplasm. In such trials, the seed of the new germplasm is usually known to be disease-free, while the health status of the seed potatoes of the local varieties is almost invariably unknown.

To understand the real cause(s) of low adoption of new varieties, which would in turn inform future variety development efforts in Ethiopia, it is important to work directly with farmers and use healthy seed in all trials. Participatory variety selection (PVS) brings breeders, farmers and social scientists together to identify gaps in the crop adoption process and to target and prioritize traits of importance (Almekinders and Elings 2001; Bellon 2002). PVS is a widely used approach that provides farmers with a choice of genotypes (varieties and advanced materials) that can be evaluated under social and agroecological conditions of relevance to the farmers (Weltzien et al. 2000; Almekinders and Elings 2001; Gibson et al. 2008). PVS has proven helpful when breeders want to improve upon the rate of improved variety adoption (Almekinders and Elings 2001; Mulatu and Zelleke 2002; Bellon 2002; Danial et al. 2007), and for ascertaining gender differences in selection criteria (Bellon 2002; Vom Brocke et al. 2010).

The objectives of this study were: 1) to characterize major production challenges in two growing seasons and in two major agroecological zones in northwest Ethiopia; 2) to identify farmer variety selection criteria and assess their relative importance among gender groups and agroecological zones using a PVS approach; 3) to assess specific characteristics of major local and new varieties as perceived by farmers; and 4) to measure the agronomic performance of local varieties compared to the most successful new cultivars using breeders' selection criteria (tuber yield, late blight resistance and tolerance to drought and other major abiotic stresses).

\section{Material and Methods}

\section{Study Locations, Planting Seasons and Varieties}

A PVS approach was adapted from the guidelines of the Africa Rice Center (Africa Rice Center 2010), and a design was established to enable breeders and social scientists to effectively collect data on important parameters with the participation and cooperation of farmers.

Six major potato-growing districts in Ethiopia were surveyed during 2012 and 2014 to assess the diversity of varieties grown by farmers (Kolech et al. 2015). Based on this survey, two districts (Yilmana and Laigaint) were selected in northwest Ethiopia representing different agroecological conditions, market outlets and food security levels, but sharing similar farming systems (the same growing seasons and, the same crops such as barley, potato and a few legumes). The district of Yilmana (2800 m, located at $11^{\circ} 16^{\prime} \mathrm{N}$ latitude and $37^{\circ} 28^{\prime} \mathrm{E}$ longitude) has a wet agroecology while Laigaint $(3100 \mathrm{~m}$, located at $11^{\circ} 43^{\prime} \mathrm{N}$ latitude and $38^{\circ} 28^{\prime}$ E longitude) represents dry agroecology with less dependable rainfall. Farmers in Laigaint are food insecure and potato is the primary source of food. In both districts, potatoes are planted in Belmehr and Meher seasons. The average 5-year rainfall distribution for the two locations is shown in Fig 1. Twelve potato varieties (9 local and 3 new varieties) with diverse traits (early and late maturing, white, purple and red color tubers, short and tall plants, etc.) were included in the study. The local varieties were collected from major potato producing areas of Ethiopia during our survey in 2012, tested for plant pathogens and multiplied in vitro to produce seed. The new varieties were developed and released by the Ethiopian Agricultural Research Institutes in collaboration with the International Potato Center (CIP). The local and new varieties were planted in four environments (two districts $\mathrm{X}$ two seasons). A description of varieties included in the study is shown in Table 1.

\section{Design of the Experiment and Field Management}

The sites for the experiment were selected as representative farms in terms of fertility status, soil type and topography. Before planting, soil testing was done in each of the two sites representing the two districts. Three soil samples were collected at each site using an auger to a depth of $20 \mathrm{~cm}$. Three samples from each site were bulked together and immediately 
Fig. 1 Annual rainfall for the study sites in 2014 and the last 5years average during four seasons (Belg, Belmehr, Meher and Mesino)

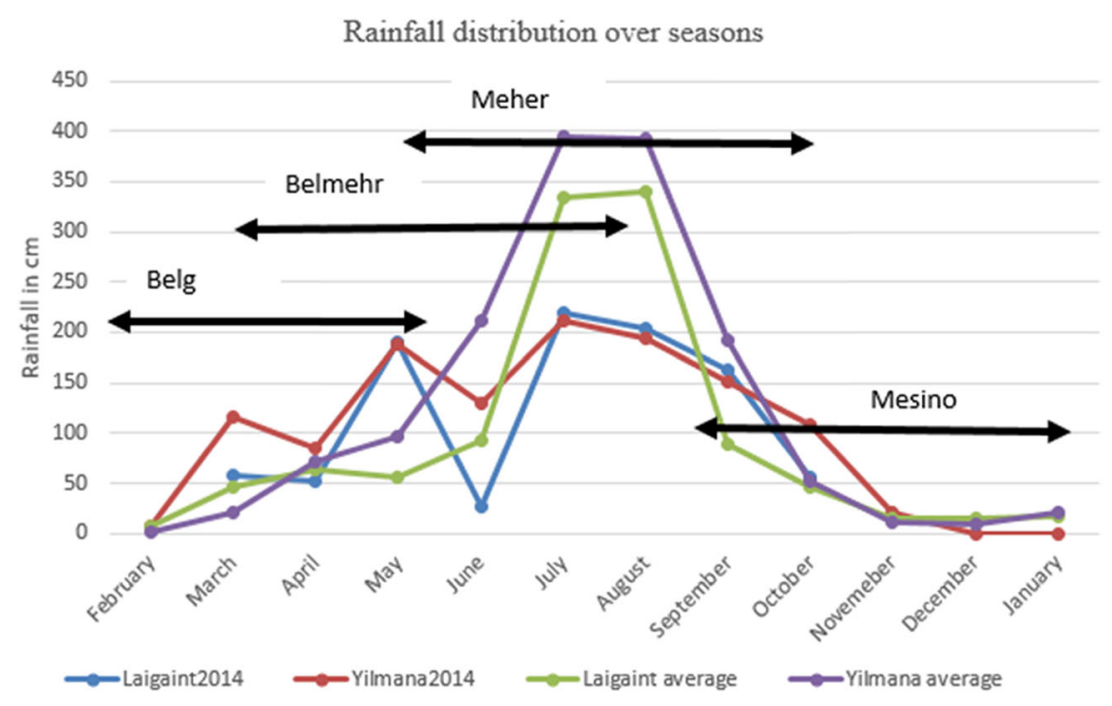

sent to the national soil laboratory in Addis Ababa for analysis.

In order to assess the performance of varieties, plots were laid out in a randomized complete block design with three replications of $9 \mathrm{~m}^{2}$ plots for each variety in each district and season. The field trials were managed jointly by researchers and farmers. Animal traction was used to plant the varieties during Belmehr season for both locations; ridging (hilling) was done after the plants emerged. For Meher season production, however, ridging was done at planting as recommended by Gebremedhin et al. (2008). Ridomil was sprayed at the rate of $4 \mathrm{~kg} / \mathrm{ha}$ for late blight protection during the Meher season, twice at Laigaint and once at Yilmana.

\section{Selection of Farmers and Data Collection}

Two farmers' research groups (FRGs) consisting of 7 women and 28 men at Yilmana (total of 35 farmers) and 17 women and 22 men at Laigaint (total of 39 farmers) were organized. The selection of farmers was village based (living in the same village) and participation was voluntary. The groups evaluated varieties at the time of flowering, harvest and post-harvest

Table 1 Varieties included in participatory variety selection at Laigaint and Yilmana in 2014

\begin{tabular}{|c|c|c|c|}
\hline Variety & Origin $^{\mathrm{a}}$ & Maturity and other characteristics ${ }^{\mathrm{b}}$ & Where produced \\
\hline Enat Beguaro & Local & Medium late, no flowering, high number of white tubers & Sinan District (Amhara region) \\
\hline Abadamu & Local & Medium early, late flowering, market desired tuber size & Quarit District (Amhara region) \\
\hline Siquare & Local & Early, round red tubers, widely grown & $\begin{array}{l}\text { Mid to cool highlands of northwest Ethiopia } \\
\text { (Amhara region) }\end{array}$ \\
\hline Feleke & Local & Very late, late flowering, round white tubers & Chencha District (SNNP region) \\
\hline Bulle Local & Local & Medium early, early flowering, round purple tubers & Kofele district (Oromia region) \\
\hline Nech Abeba & Local & Medium early, round white tubers & $\begin{array}{l}\text { Shashemene and surrounding areas (SNNP } \\
\text { and Oromia regions) }\end{array}$ \\
\hline Key Shull & Local & Very early, early flowering, oval tubers & Shasho District (SNNP region) \\
\hline Rejim China & Local & $\begin{array}{l}\text { Late, tall plants, white tubers with pink pigment } \\
\text { around the eyes }\end{array}$ & Kofele District (Oromia region) \\
\hline Abalo & Local & $\begin{array}{l}\text { Late maturing, tubers noted for flavor but not attractive, } \\
\text { widely grown }\end{array}$ & Cool highlands in northwest Ethiopia \\
\hline Gera & New & Early maturing, round tubers with deep eyes & $\begin{array}{l}\text { Reported to be well adapted to dry areas } \\
\text { above } 2700 \mathrm{~m} \text {. }\end{array}$ \\
\hline Jalene & New & Medium early, early flowering, russet tubers & $\begin{array}{l}\text { Reported as widely adapted variety } \\
\text { in Ethiopia }\end{array}$ \\
\hline Belete & New & Early maturing, high yielding, late blight tolerant & Reported as widely adapted \\
\hline
\end{tabular}

${ }^{a}$ Origin refers to distinguishing between locally cultivated varieties, 'Local', versus those more recently introduced varieties, 'New'

${ }^{\mathrm{b}}$ Varieties were grouped into six maturity classes; very early (<90 days), early (90-100), medium early (101-110), medium late (111-120), late (121$130)$ and very late (>130 days) based on Belmehr season production 
following strategies described in the Technician's Manual for participatory variety selection of rice (Africa Rice Center 2010). At each location the harvested tubers were stored in a relatively cool, dark place within the home of one of the FRG members, and assessment of storage quality was made after 3 months of storage. Data on the socioeconomic status of the FRG members was collected, and during each field visit, FRG members were separated by gender and asked to rate the varieties and indicate the reasons why they chose them.

In addition to farmers' evaluations, data were collected by the research team on yield, date of flowering and maturity and other marketable traits of the varieties as well as their response to late blight, wind and hail damage.

\section{Data Analysis}

Average tuber weight, marketable tuber yield (excluding tubers that were less than $30 \mathrm{~g}$, diseased or deformed) and total tuber yield in each environment (combined among seasons and locations) were calculated and analysis of variance of the varieties computed using JMP software (JMP PRO 10.0.2). Analysis of the trait ratings was also computed using this software. An Additive Main effects and Multiplicative Interaction (AMMI) model was used to partition variety by environment interaction and to construct biplots. AMMI analysis was computed using Genstat software (Genstat 2013). Descriptive statistics and frequencies were also calculated to obtain the highest-ranking traits between gender groups.

\section{Results}

\section{Grower-Identified Factors Affecting Potato Production}

Several factors that limit production were identified by farmers in both districts and cropping seasons. Growers were asked to rank the factors they identified on a scale of 1 ("less important") to 3 ("very important"). Generally, farmers cited 8 factors as "very important" (Table 2), with late blight rated as "very important" by nearly all of the farmers in both districts. However, the significance and extent of other problems differed between districts and cropping seasons. Although drought (unreliable and erratic rainfall) is a very important parameter for the Belmehr season in both districts, it was rated higher at Laigaint than Yilmana. Other factors rated as "very important" by the majority of the farmers in a given district were desiccating wind and low soil fertility at Laigaint and severe precipitation and hail damage at Yilmana. In Yilmana, the crop was exposed to hail three times in the Meher season, resulting in the poor performance of most varieties. At Laigaint during the Meher season, desiccating wind starting in September coupled with terminal moisture stress resulted in lodging and drying of the plants. Tuber spoilage in the soil and in storage as well as small tuber size (defined as not fit for market demand or less than $30 \mathrm{~g}$ weight) were also major problems in both locations. Bird damage on tubers is a common problem during planting and harvesting at Laigaint. We also observed red ants during harvest of tubers and took weight measurement of the affected tubers. The ratio of the weight of affected tubers in relation to total tuber weight in each variety showed a tuber quality loss up to $29 \%$ due to red ant damage in the Meher season at Laigaint.

An AMMI model based on total tuber yield shows distinct clustering of the four environments (Meher and Belmehr seasons in Laigaint and Yilmana districts) (Fig. 2). Two environments (Meher at Yilmana and Belmehr at Laigaint) on the AMMI plot were more closely related to each other than the rest of the environments. This suggests that challenges caused by abiotic stresses were equally important in these environments. Most early maturing varieties clustered on the Meher season quadrant and close to the origin indicating these varieties are more suitable for Meher season production in both districts. In contrast, late maturing varieties are far from the origin but grouped on the Belmehr season in one of the districts indicating that these varieties are better adapted to Belmehr season production.

\section{Soil Sample Testing}

The result of the soil analysis is shown in Table 3. The data shows that an important nutrient, potassium, is far below optimum in both sites. Moreover, the organic carbon content and total available nitrogen are at levels below those recommended for good crop growth, indicating soil fertility and possibly water holding capacity and drainage constraints to optimum productivity at both sites. For phosphorus, the soil in Laigaint was much lower than that of Yilmana. Moreover, the soil in Laigaint is more acidic than that of Yilmana.

\section{Potato Traits Important to Farmers by Agroecological Zone and Gender}

Potato traits important to farmers were revealed by the responses farmers gave in the process of selecting varieties. Twenty-three traits were identified during farmers' evaluation of varieties at flowering, harvest, and in storage in both seasons and districts (Tables 4 and 5). At the pre-flowering and flowering stages, farmers were more concerned about morphological characteristics such as ground foliage cover, leaf size, stem thickness and leaf strength, flowering status, late blight resistance and others. At harvest, growers were more concerned about tuber yield and tuber characteristics such as tuber size, tuber number, tolerance to lodging due to wind at Laigaint and tolerance to hail damage at Yilmana, time to maturity, and other factors. After harvest, the farmers were more concerned with taste, tuber storage quality and tuber sprout number. 
Table 2 Production problems that farmers rated as "very important" in two locations

\begin{tabular}{llcc}
\hline Production challenges* & Target seasons & \multicolumn{2}{l}{ Percent of farmers rating production problems as "very important" } \\
\cline { 3 - 4 } & & Laigaint & Yilmana \\
\hline Bird damage & Meher and Belmehr & 45.9 & 14.7 \\
Drought & Both, mainly Belmehr & 100.0 & 85.3 \\
Unmarketable tuber size (for market purpose) & Both, mainly Belmehr & 62.2 & 67.6 \\
Desiccating wind & Both, mainly Meher & 78.4 & NL \\
Heavy rainfall load \& Hail damage & Meher & NL & 70.6 \\
Late blight & Both, mainly Meher & 94.6 & 97.1 \\
Low soil fertility & Both, mainly Belmehr & 75.7 & 50.0 \\
Tuber spoilage & Meher and Belmehr & 73.0 & 70.6 \\
\hline
\end{tabular}

$N L$ not listed as a production problem; "low importance" and "very important" corresponded to 1 and 3, respectively on a scale of 1 to 3

The degree of importance of these traits differed between districts and gender groups. Traits such as drought tolerance, adaptation to soil with low fertility, long stolons, tolerance to bird damage and suitability for multiple harvesting received significantly higher ratings at Laigaint than at Yilmana (Table 4). At Yilmana, however, stew quality and market demand were of greater concern than at Laigaint. This correlates with market access; almost all of the farmers in Yilmana sold their produce in markets at least once that year, while only $33.3 \%$ of the farmers did so at Laigaint.

A comparison of rankings by men and women shows a significant difference for a few traits at Laigaint but not at Yilmana (Table 4), but on the whole concerns for most traits do not differ by gender. In Laigaint, low soil fertility and market demand are more important concerns for men than women while a long stolon (which is related to the ability to harvest the crop two or more times in the same season) is of greater concern to women than to men. Food insecurity is a common problem in Laigaint due to frequent drought. Women are more concerned with filling the food security gap and want varieties that have a slow tuber-bulking rate. Men are more concerned with market demand and prefer the most profitable varieties to resolve their immediate cash problems.

\section{Farmers' Perception of Characteristics of the Studied Varieties}

Specific variety characteristics that farmers pay attention to during flowering, harvesting and after 3 months of storage are shown in Table 6. All of the southern Ethiopian (SNNP and Oromia) local varieties, as well as one new variety ('Jalene') were found to have short storability. Farmers' ratings of storability after 3 months storage are shown in Fig. 3. Two of the new varieties ('Belete' and 'Gera') and the local variety 'Siquare' have intermediate storage life although farmers complained that 'Belete' does not store well in typical 'in-home' storage. 'Abalo' and 'Abadamu' (local varieties from northwest Ethiopia) have excellent storability. Varieties also differed with regard to suitability for boiling and stew making quality. 'Abalo' has excellent taste after boiling and is good for making stew, while 'Abadamu' is ranked the lowest for boiling but can be used for stew. 'Belete' has excellent stew quality but is not appreciated as a boiling potato. Varieties with good physical appearance and desirable tuber size meet the demands of markets in Yilmana and surrounding areas. For purposes of marketing, tubers of 'Abalo' are not considered sufficiently attractive. Adequate tuber size is related to marketability of their produce, and this may affect grower decisions, as the tubers produced in the Belmehr season are
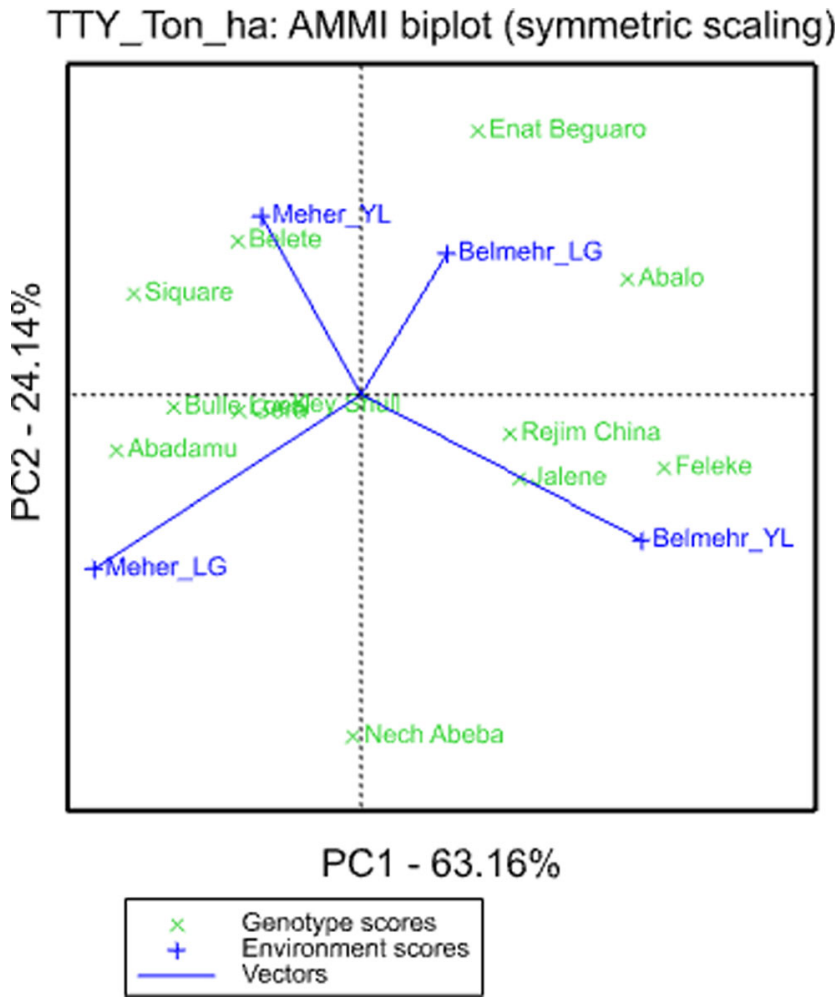

Fig. 2 An AMMI biplot showing the relationship of variety and environment in terms of total tuber yield (tons/ha) 
Table 3 The availability of different soil nutrients based on soil testing

\begin{tabular}{|c|c|c|c|c|c|c|c|c|}
\hline Site & $\mathrm{pH}$ & $\mathrm{K}$ (Cmol/kg soil) & $\mathrm{CEC}$ & T.N (\%) & O.C $(\%)$ & $\mathrm{Fe}(\mathrm{PPM})$ & $\mathrm{Zn}(\mathrm{PPM})$ & Av.P (PPM) \\
\hline Yilmana & 6.85 & 3.08 & 43.07 & 0.21 & 2.55 & 30.47 & 56.54 & 31.14 \\
\hline Laigaint & 5.67 & $\mathrm{ND}$ & 25.91 & 0.22 & 2.06 & 51.72 & 22.49 & 7.19 \\
\hline Low level & $5.5^{\mathrm{a}}$ & $<60^{\mathrm{a}}$ & $5^{b}$ & & $3^{\mathrm{b}}$ & $<3^{\mathrm{b}}$ & $<1^{\mathrm{b}}$ & $<7^{\mathrm{a}}$ \\
\hline
\end{tabular}

ND indicates results with less than methods detection limit; $K$ potassium, $C E C$ cation exchange capacity, T.N total nitrogen, $O . C$ organic carbon content, Fe iron, $Z n$ zinc, Ave. $P$ available phosphorus

$\mathrm{a}=$ based on the minimum level standards of Colorado State University, http://www.ext.colostate.edu/pubs/crops/00541.html, accessed on 6/4/2015

$\mathrm{b}=$ based on the minimum level standards of the University of Maine, http://anlab.umesci.maine.edu/soillab_files/under/com, accessed on 6/4/2015

typically small and do not attract good market prices. Varieties such as 'Bulle local', 'Key Abeba', 'Enat Beguaro' and 'Rejim China' gave the lowest average tuber weight.

The relative importance of long stolons, a trait that facilitates sequential harvests of the crop in a single growing season, differed between districts. Multiple harvests are only practiced during the Belmehr season and with late maturing varieties. Varieties with long and numerous stolons are also good for combating bird damage since birds cannot access the tubers easily.

Farmers in both districts grow varieties with distinct characteristics. The degree to which farmers consider each of these traits to be important in four widely grown varieties is summarized in

Table 4 Average ratings of potato variety trait importance by district and gender

\begin{tabular}{|c|c|c|c|c|c|c|c|c|c|}
\hline \multirow[t]{2}{*}{ Traits } & \multicolumn{3}{|c|}{ Laigaint } & \multicolumn{3}{|c|}{ Yilmana } & \multicolumn{3}{|c|}{ Location mean } \\
\hline & Male & Female & Prob $>X^{2 *}$ & Male & Female & Prob $>X^{2}$ & Laigaint & Yilmana & Prob $>X^{2}$ \\
\hline \multicolumn{10}{|l|}{ Biotic and abiotic tolerance } \\
\hline Drought tolerance & 3.00 & 3.00 & NS & 2.79 & 3.00 & NS & 3.00 & 2.85 & 0.005 \\
\hline Low soil fertility adaptation & 2.90 & 2.36 & 0.029 & 2.43 & 2.57 & NS & 2.70 & 2.47 & 0.038 \\
\hline Bird damage tolerance & 2.45 & 2.36 & NS & 1.54 & 2.00 & NS & 2.41 & 1.65 & 0.000 \\
\hline Late blight resistance & 2.90 & 3.00 & NS & 2.93 & 3.00 & NS & 2.95 & 2.94 & NS \\
\hline Wind and hail damage tolerance & 2.65 & 2.86 & NS & 2.61 & 2.86 & NS & 2.76 & 2.68 & NS \\
\hline Tuber spoilage tolerance & 2.65 & 2.57 & NS & 2.57 & 2.86 & NS & 2.65 & 2.65 & NS \\
\hline \multicolumn{10}{|l|}{ Agronomic traits } \\
\hline Long shelf life & 2.95 & 3.00 & NS & 2.93 & 3.00 & NS & 2.97 & 2.94 & NS \\
\hline Long root and stolon system & 2.10 & 2.21 & 0.047 & 1.46 & 1.29 & NS & 2.16 & 1.38 & 0.000 \\
\hline Large plant height & 1.75 & 1.71 & NS & 1.32 & 1.14 & NS & 1.78 & 1.26 & 0.001 \\
\hline Large leaves & 2.25 & 2.14 & NS & 2.04 & 1.57 & NS & 2.22 & 1.94 & NS \\
\hline Early flowering & 2.35 & 1.93 & NS & 2.14 & 1.86 & NS & 2.14 & 2.06 & NS \\
\hline Thick stem & 2.80 & 2.50 & NS & 2.43 & 2.14 & NS & 2.70 & 2.35 & NS \\
\hline Leaf strength & 2.25 & 2.50 & NS & 2.57 & 2.14 & NS & 2.35 & 2.47 & NS \\
\hline Large number of leaves & 2.15 & 2.36 & NS & 2.29 & 2.57 & NS & 2.27 & 2.32 & NS \\
\hline Large number of sprouts & 2.60 & 2.43 & NS & 2.50 & 2.86 & NS & 2.57 & 2.59 & NS \\
\hline Early maturity & 2.55 & 2.29 & NS & 2.50 & 2.29 & NS & 2.41 & 2.44 & NS \\
\hline Sequential harvesting & 2.95 & 3.00 & NS & 2.75 & 2.86 & NS & 2.97 & 2.79 & 0.013 \\
\hline High yield & 3.00 & 3.00 & NS & 3.00 & 3.00 & NS & 3.00 & 3.00 & NS \\
\hline Tuber size & 2.55 & 2.71 & NS & 2.75 & 2.43 & NS & 2.59 & 2.68 & NS \\
\hline Tuber number & 2.40 & 2.43 & NS & 2.18 & 2.57 & NS & 2.43 & 2.26 & NS \\
\hline \multicolumn{10}{|l|}{ Utilization } \\
\hline Suitability for boiling & 3.00 & 2.93 & NS & 3.00 & 3.00 & NS & 2.97 & 3.00 & NS \\
\hline Suitability for stew & 2.95 & 2.79 & NS & 3.00 & 3.00 & NS & 2.86 & 3.00 & 0.009 \\
\hline Market demand & 2.75 & 2.29 & 0.0372 & 2.82 & 2.86 & NS & 2.57 & 2.82 & NS \\
\hline
\end{tabular}

${ }^{*} P$ value associated with $\mathrm{X}^{2}$ test using Kruskal's rank test. Ratings are on a scale of 1 to 3, where 1 is low importance and 3 is very important 
Table 5 Percent of farmers rating traits as "very important"

\begin{tabular}{|c|c|c|c|c|c|c|}
\hline \multirow[t]{3}{*}{ Traits } & \multicolumn{6}{|c|}{ Percent of farmers rating traits as "very important" } \\
\hline & \multicolumn{3}{|c|}{ Laigaint } & \multicolumn{3}{|c|}{ Yilmana } \\
\hline & Male & Female & Both & Male & Female & Both \\
\hline \multicolumn{7}{|l|}{ Biotic and abiotic tolerance } \\
\hline Drought tolerance & 100 & 100 & 100 & 78.6 & 100 & 89.3 \\
\hline Low soil fertility adaptation & 90.0 & 50.0 & 70.0 & 46.4 & 57.1 & 51.8 \\
\hline Tolerance to bird damage & 50.0 & 42.9 & 46.4 & 10.7 & 28.6 & 19.6 \\
\hline Late blight resistance & 90.0 & 100 & 95.0 & 96.4 & 100 & 98.2 \\
\hline Tolerance to tuber spoilage & 75.0 & 64.3 & 69.6 & 64.3 & 85.7 & 75.0 \\
\hline Tolerance to wind and hail damage & 70.0 & 85.7 & 77.8 & 64.3 & 85.7 & 48.2 \\
\hline \multicolumn{7}{|l|}{ Agronomic traits } \\
\hline Long root system & 50.0 & 42.9 & 46.4 & 10.7 & 0.0 & 5.3 \\
\hline Large plant height & 15.0 & 14.3 & 14.6 & 0.0 & 0.0 & 0.0 \\
\hline High yield & 100 & 100 & 100 & 100 & 100 & 100 \\
\hline Large leaves & 40.0 & 28.6 & 34.3 & 17.9 & 0.0 & 8.9 \\
\hline Early flowering & 50.0 & 35.7 & 42.8 & 32.1 & 14.3 & 23.2 \\
\hline Thick stem & 80.0 & 57.1 & 68.6 & 50.0 & 42.9 & 46.4 \\
\hline Leaf strength & 35.0 & 64.3 & 49.6 & 60.7 & 28.6 & 44.6 \\
\hline Large number of leaves & 35.0 & 42.9 & 38.9 & 39.3 & 71.4 & 55.4 \\
\hline Large number of sprouts & 65.0 & 42.9 & 53.9 & 53.6 & 85.7 & 69.6 \\
\hline Early maturity & 55.0 & 57.1 & 56.1 & 60.7 & 57.1 & 58.9 \\
\hline Tuber size & 60.0 & 71.4 & 65.7 & 75.0 & 42.8 & 58.9 \\
\hline Tuber number & 40.0 & 42.9 & 41.4 & 21.4 & 57.1 & 39.3 \\
\hline Long shelf life & 95.0 & 100 & 97.5 & 92.9 & 100 & 96.4 \\
\hline Suitable for sequential harvesting & 95.0 & 100 & 97.5 & 75.0 & 85.7 & 80.4 \\
\hline \multicolumn{7}{|l|}{ Utilization } \\
\hline Suitability for boiling & 100 & 92.9 & 96.4 & 100 & 100 & 100 \\
\hline Suitability for stew & 95.0 & 78.6 & 86.8 & 100 & 100 & 100 \\
\hline Market demand & 75.0 & 35.7 & 55.3 & 82.1 & 85.7 & 83.9 \\
\hline Sample size & 20 & 14 & & 28 & 7 & \\
\hline
\end{tabular}

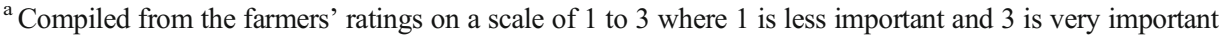

Table 7. The four varieties were significantly different from each other in 22 of the 23 traits evaluated. Based on the nine most important traits common to both districts (considered "very important" by more than $70 \%$ of the farmers), 'Abalo', 'Belete' and 'Siquare' have 9, 7 and 5 important traits, respectively, while 'Jalene' has the lowest (3 traits). Moreover, 'Abalo' has the additional trait advantage at Laigaint of its adaptation for poor soil fertility while the rest of the varieties have the additional advantage of market demand at Yilmana.

\section{Agronomic Performance of Local Potato Varieties Compared to Improved Varieties in Different Environments}

The ANOVA and AMMI analyses indicated that there are significant differences among varieties, between environments and in variety by environment interactions in terms of average tuber weight, marketable and total tuber yields. Most of the tested varieties gave higher marketable and total tuber yield at Laigaint in the Meher season versus both districts in the Belmehr cropping season. The lowest yield was recorded at Yilmana during the Meher season due to repeated hail damage. Early bulking varieties such as 'Belete' and 'Gera' (new), and'Nech Abeba' and 'Abadamu' (local) yielded well (marketable and total yield) in both Meher and Belmehr seasons. Unsurprisingly, late maturing local varieties such as 'Abalo' and 'Rejim China' had higher marketable yield in the Belmehr season compared to the Meher season (Table 8). 'Bulle Local' and 'Feleke' had high total tuber yield in both seasons at Laigaint and in the Belmehr season at Yilmana, but their marketable yields were low.

The performance of varieties in relation to late blight, lodging due to wind and damage due to hail is shown in Fig. 4. Two new varieties, 'Belete' and 'Gera', and one local variety, 'Siquare', showed resistance to late blight while the other varieties were variably affected. In Laigaint during the 
Table 6 Variety characteristics perceived by farmers at flowering, during harvest, and after 3 months of storage

\begin{tabular}{|c|c|c|}
\hline Variety & Positive traits & Negative traits \\
\hline Enat Beguaro & $\begin{array}{l}\text { High number of stems and high tuber number per plant, } \\
\text { suitable for multiple harvests, tasty tubers, easily peeled } \\
\text { after cooking }\end{array}$ & $\begin{array}{l}\text { Susceptible to late blight, weak stems and leaves, } \\
\text { tubers take long time to cook, poor storage quality }\end{array}$ \\
\hline Abadamu & $\begin{array}{l}\text { Very large leaf size (good soil cover), market desired tuber size, } \\
\text { shallow eye depth, good storage quality }\end{array}$ & $\begin{array}{l}\text { Susceptible to late blight, poor taste after boiling, } \\
\text { weak stems }\end{array}$ \\
\hline Siquare & $\begin{array}{l}\text { Good canopy cover because of high number of leaves, early } \\
\text { maturing, good for stew, intermediate storage quality, good } \\
\text { market demand in nearby towns }\end{array}$ & $\begin{array}{l}\text { Smooth tubers, the tubers are not as good as Abalo for boiling } \\
\text { (Laigaint), apical dominance in sprout formation (low } \\
\text { number of stems) }\end{array}$ \\
\hline Feleke & Tall plant height & $\begin{array}{l}\text { Small tubers, poor storage quality, very late maturing, } \\
\text { susceptible to late blight }\end{array}$ \\
\hline Bulle Local & Large leaf size, thick stems & $\begin{array}{l}\text { Susceptible to late blight, purple tuber color is not attractive, } \\
\text { weak and delicate leaves, very poor storage quality }\end{array}$ \\
\hline Nech Abeba & $\begin{array}{l}\text { Tall plant height, attractive round white tubers, high average } \\
\text { tuber weight, thick stems }\end{array}$ & Susceptible to late blight, very poor storage quality \\
\hline Key Shull & Very early maturing, firm after cooking & $\begin{array}{l}\text { Very short plant, highly susceptible to late blight, not tolerant } \\
\text { of wind, heavy rainfall, or low temp; very poor storage quality }\end{array}$ \\
\hline Rejim China & $\begin{array}{l}\text { Good height, good tolerance to lodging from strong winds, } \\
\text { high total tuber yield }\end{array}$ & Late maturing, tubers not tasty, poor storage quality \\
\hline Abalo & $\begin{array}{l}\text { Thick stems, good adaptation to low soil fertility, moderate } \\
\text { tolerance to drought after emergence, moderate tolerance } \\
\text { to bird damage, suitable for multiple harvests, very good } \\
\text { storage quality, suitable for boiling potato and stew }\end{array}$ & $\begin{array}{l}\text { Susceptible to late blight, late maturing, the tubers are not } \\
\text { attractive in large markets }\end{array}$ \\
\hline Gera & $\begin{array}{l}\text { Large plants, relatively tolerant to late blight, intermediate } \\
\text { storage quality }\end{array}$ & $\begin{array}{l}\text { Weak stems, susceptible to early blight, poor taste when boiled, } \\
\text { deep eyes, medium storability }\end{array}$ \\
\hline Jalene & Early flowering and maturity, high yield, good for boiling & Weak stems, tubers disintegrate when cooked, poor storage quality \\
\hline Belete & $\begin{array}{l}\text { Large leaves, strong stems, good tolerance to strong winds, } \\
\text { high yield, good tuber size, early bulking, early maturing, late } \\
\text { blight resistant, good stew quality }\end{array}$ & $\begin{array}{l}\text { Quality after long storage is not as good as widely grown varieties, } \\
\text { occasional unhealthy feeling in the throat after eating and 'stony' } \\
\text { if cooled after boiling }\end{array}$ \\
\hline
\end{tabular}

Meher season, local varieties 'Feleke', 'Nech Abeba', 'Rejim China' and 'Bulle Local' and one new variety ('Belete') showed some tolerance to lodging from wind while 'Belete' and 'Abalo' showed some tolerance to hail damage at Yilmana in the Meher season. All of the varieties that showed tolerance to wind and hail damage have thick stems compared to susceptible varieties.

\section{Discussion}

Both the farmers' ratings for factors that limit production and the Additive Main effect and Multiplication Interaction Model (AMMI) analysis on tuber yield showed that there are clear differences between the Behlmehr and Meher seasons and the two agroecological zones studied in relation to potato variety performance. Although the degree of importance differs between locations, erratic rainfall patterns in the Belmehr season and late blight in Meher season are important limiting factors. Bekele and Eshetu (2008) stressed the importance of late blight in the Meher season that forces farmers to plant in the dry season (Belg or Belmehr) even if the farmers are aware that yield will be reduced. Moreover, as we observed during the Meher season, heavy rainfall and hail damage in Yilmana and high and desiccating wind in Laigaint are limiting factors for most late maturing varieties.

All of these production challenges relate to farmers' existing practices and the varieties under possession. Other production problems not cited by farmers may be relevant when new varieties are introduced. For instance, as indicated in Tables 4 and 5, traits such as long storability, sequential harvesting and culinary qualities are ranked highly by farmers in both locations and gender groups. However, farmers did not mention these traits as a production challenge because they already have varieties that provide these qualities.

Moreover, the soil sample analysis shows that soils in both locations were potassium depleted. Potassium depletion might be one of the factors for low yields at both sites. This deficiency is known to reduce crop yield (Umar and Moinuddin 2001) and increase susceptibility to different stresses (Brady and Weil 2002). Farmer rating of variety traits also shows that the ability to grow on low fertility soil is important. Unavailability of potassium fertilizer in the country coupled with inadequate chemical fertilizer application may limit potato production in these agroecological zones. It is worth noting that the Adet Agricultural Research Center (Tesfaye et al. 
Fig. 3 Farmers' rating of varieties in terms of quality 3 months after storage. Data was compiled from farmer ratings on a scale of 0 to $4 ; 0$ denotes poor storability while 4 is long storability in farmers' in-house storage
Mean rating

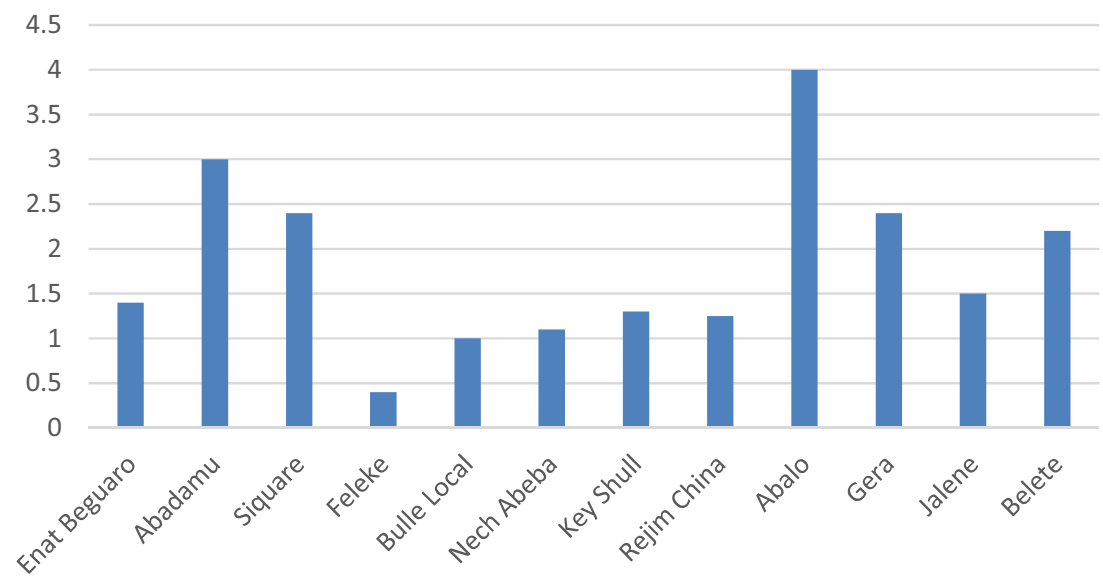

2008) does not currently recommend potassium fertilizer for potatoes. The low emphasis placed on potassium in Ethiopia today is likely the result of a 47-year old study reporting that Ethiopian soils are rich in potassium (Murphy 1968).
Variability in local conditions and between seasons contributes to the diversity of varieties that farmers choose to grow in Yilmana and Laigaint. 'Abalo' and 'Siquare' are local varieties that are grown in the Belmehr season in both districts
Table 7 Farmers' ratings of four widely grown varieties based on several important traits

\begin{tabular}{|c|c|c|c|c|c|}
\hline Traits & Abalo & Siquare & Belete & Jalene & Prob $>X^{2 a}$ \\
\hline \multicolumn{6}{|l|}{ Biotic and abiotic tolerance } \\
\hline Drought tolerance $^{\mathrm{b}}$ & 3.00 & 1.00 & 2.71 & 1.00 & 0.0001 \\
\hline Low soil fertility adaptation ${ }^{\mathrm{c}}$ & 2.77 & 1.00 & 1.29 & 1.00 & 0.0001 \\
\hline Bird damage tolerance & 2.92 & 1.00 & 1.14 & 1.00 & 0.0001 \\
\hline Late blight resistance ${ }^{\mathrm{b}}$ & 1.80 & 2.00 & 3.00 & 1.67 & 0.0001 \\
\hline Winds and hail damage tolerance ${ }^{b}$ & 2.54 & 1.27 & 3.00 & 1.33 & 0.0001 \\
\hline Tuber spoilage tolerance ${ }^{\mathrm{b}}$ & 2.85 & 2.36 & 2.57 & 1.00 & 0.0002 \\
\hline \multicolumn{6}{|l|}{ Agronomic traits } \\
\hline Long shelf life ${ }^{b}$ & 3.00 & 2.19 & 2.00 & 1.17 & 0.0001 \\
\hline Long root and stolon system & 2.62 & 1.09 & 1.00 & 1.50 & 0.0001 \\
\hline Large leaves & 1.92 & 1.27 & 2.86 & 2.33 & 0.0001 \\
\hline Early Flowering & 1.00 & 3.00 & 2.86 & 3.00 & 0.0001 \\
\hline Thick stem & 2.00 & 1.91 & 2.71 & 2.67 & 0.0008 \\
\hline Leaf strength & 2.31 & 1.00 & 2.86 & 1.50 & 0.0001 \\
\hline Large number of leaves & 1.77 & 3.00 & 2.71 & 2.50 & 0.0001 \\
\hline Large number of sprouts & 2.00 & 2.73 & 2.29 & 2.67 & 0.0310 \\
\hline Early maturity & 1.00 & 3.00 & 3.00 & 2.83 & 0.0001 \\
\hline Sequential harvesting ${ }^{\mathrm{b}}$ & 3.00 & 1.00 & 1.00 & 1.00 & 0.0001 \\
\hline High yield $^{\mathrm{b}}$ & 2.07 & 2.23 & 3.00 & 2.83 & 0.0001 \\
\hline Tuber size & 1.85 & 2.91 & 3.00 & 2.83 & 0.0001 \\
\hline Tuber number & 2.54 & 2.49 & 3.00 & 2.83 & NS \\
\hline \multicolumn{6}{|l|}{ Utilization } \\
\hline Taste as boiled potato ${ }^{\mathrm{b}}$ & 3.00 & 2.18 & 2.14 & 2.17 & 0.0001 \\
\hline Suitability as table potato ${ }^{b}$ & 3.00 & 1.18 & 1.43 & 1.83 & 0.0001 \\
\hline Stew quality ${ }^{\mathrm{b}}$ & 3.00 & 2.45 & 2.86 & 2.00 & 0.0016 \\
\hline Market demand ${ }^{\mathrm{d}}$ & 1.92 & 2.73 & 3.00 & 2.67 & 0.0002 \\
\hline
\end{tabular}

${ }^{\mathrm{a}}$ Kruskal-Wallis rank test; Rating on a scale of 1 to 3 where 1 is less important and 3 is very important

${ }^{\mathrm{b}}$ Very important traits for both districts, ${ }^{\mathrm{c}}$ very important trait for Laigaint, ${ }^{\mathrm{d}}$ very important trait for Yilmana 
Table 8 Marketable (MTY) and total tuber yield (TTY) in tons/ha of the varieties tested during 2014 in two different seasons and two districts

\begin{tabular}{|c|c|c|c|c|c|c|c|c|}
\hline \multirow[t]{3}{*}{ Variety } & \multicolumn{4}{|l|}{ Laigaint } & \multicolumn{4}{|l|}{ Yilmana } \\
\hline & \multicolumn{2}{|l|}{ Belmehr } & \multicolumn{2}{|l|}{ Meher } & \multicolumn{2}{|l|}{ Belmehr } & \multicolumn{2}{|l|}{ Meher } \\
\hline & MTY* & TTY & MTY & TTY & MTY & TTY & MTY & TTY \\
\hline Enat Beguaro & $9.1 \mathrm{bc}$ & $14.8 \mathrm{abc}$ & $5.0 \mathrm{f}$ & $11.7 \mathrm{e}$ & $2.6 \mathrm{e}$ & $12.4 \mathrm{c}$ & $0.9 \mathrm{~d}$ & $1.3 \mathrm{~d}$ \\
\hline Abadamu & $14.0 \mathrm{ab}$ & $15.8 \mathrm{ab}$ & $20.1 \mathrm{a}$ & $24.0 \mathrm{a}$ & $12.5 \mathrm{abc}$ & $15.9 \mathrm{abc}$ & $5.3 \mathrm{~b}$ & $6.8 \mathrm{~b}$ \\
\hline Siquare & $12.8 \mathrm{abc}$ & $15.1 \mathrm{abc}$ & $15.8 \mathrm{abc}$ & $21.2 \mathrm{abc}$ & $9.9 \mathrm{bcd}$ & $14.1 \mathrm{bc}$ & $5.5 \mathrm{~b}$ & $7.3 \mathrm{~b}$ \\
\hline Feleke & $9.1 \mathrm{bc}$ & $15.2 \mathrm{abc}$ & $9.5 \mathrm{def}$ & $15.5 \mathrm{de}$ & 8.0 cde & $21.5 \mathrm{a}$ & $2.3 \mathrm{~cd}$ & $3.2 \mathrm{~cd}$ \\
\hline Bulle Local & $8.4 \mathrm{c}$ & $14.4 \mathrm{abc}$ & $13.8 \mathrm{bcd}$ & $21.7 \mathrm{abc}$ & 7.5 cde & $15.6 \mathrm{abc}$ & $3.2 \mathrm{c}$ & $6.6 \mathrm{~b}$ \\
\hline Nech Abeba & $13.1 \mathrm{abc}$ & $16.0 \mathrm{ab}$ & $20.5 \mathrm{a}$ & $24.8 \mathrm{a}$ & $14.9 \mathrm{ab}$ & $22.5 \mathrm{a}$ & $4.1 \mathrm{bc}$ & $5.3 \mathrm{bc}$ \\
\hline Key Shull & $7.7 \mathrm{c}$ & $10.1 \mathrm{c}$ & 12.4 cde & $16.3 \mathrm{cde}$ & $5.7 \mathrm{de}$ & $13.4 \mathrm{c}$ & $2.4 \mathrm{~cd}$ & $3.0 \mathrm{~cd}$ \\
\hline Rejim China & $13.5 \mathrm{ab}$ & $18.8 \mathrm{a}$ & $12.6 \mathrm{cde}$ & $19.8 \mathrm{abcd}$ & $12.1 \mathrm{abc}$ & $21.0 \mathrm{abc}$ & $3.8 \mathrm{bc}$ & $5.0 \mathrm{bc}$ \\
\hline Abalo & $11.7 \mathrm{abc}$ & $16.5 \mathrm{ab}$ & $8.5 \mathrm{ef}$ & $15.4 \mathrm{de}$ & $14.4 \mathrm{ab}$ & $21.5 \mathrm{a}$ & $5.1 \mathrm{~b}$ & $7.0 \mathrm{~b}$ \\
\hline Gera & $10.7 \mathrm{abc}$ & $13.8 \mathrm{bc}$ & $18.1 \mathrm{ab}$ & $20.0 \mathrm{abcd}$ & $11.2 \mathrm{abc}$ & $15.5 \mathrm{abc}$ & $4.1 \mathrm{bc}$ & $5.3 \mathrm{bc}$ \\
\hline Jalene & $12.7 \mathrm{abc}$ & $14.7 \mathrm{abc}$ & $15.8 \mathrm{abc}$ & $18.5 \mathrm{bcd}$ & $14.2 \mathrm{ab}$ & $21.7 \mathrm{a}$ & $5.2 \mathrm{~b}$ & $6.3 \mathrm{~b}$ \\
\hline Belete & $15.6 \mathrm{a}$ & $16.8 \mathrm{ab}$ & $17.2 \mathrm{abc}$ & $22.1 \mathrm{ab}$ & $15.9 \mathrm{a}$ & $19.0 \mathrm{abc}$ & $9.6 \mathrm{a}$ & $12.2 \mathrm{a}$ \\
\hline Mean & 11.56 & 15.33 & 14.12 & 19.24 & 10.75 & 17.85 & 4.3 & 5.79 \\
\hline
\end{tabular}

${ }^{*}$ varieties with similar letters are not significantly different at $P<0.05$ while new varieties such as 'Belete' and 'Jalene' are grown mainly in the Meher season. Our study found that late maturing varieties (all local) are best suited to Belmehr season production while early bulking ones (two local and two improved varieties) are best suited to Meher season production. This is not surprising as late maturing varieties need a long growing season. Also, the short growing season coupled with late blight severity and desiccating wind contributed to low yield of late maturing varieties in Meher season production. Some of the early bulking varieties such as 'Belete', 'Abadamu' and
'Nech Abeba' performed well during Belmehr season, presumably due to the favorable rainfall distribution for potato growth as shown in Fig. 1.

Information on farmers' selection criteria is one of the important outputs of PVS (Wakijira et al. 2008). Our study showed that the farmers consider up to 23 crop traits important for variety selection in the two districts, representing two major agroecological zones. Other studies have reported that resource poor farmers give more attention to yield stability, quality, and secondary uses (Thiele et al. 1997; Almekinders
Fig. 4 Varietal differences in defoliation caused by hail (Meher season), frequency of lodging due to strong winds (Meher season) and severity of late blight (Belmehr season)

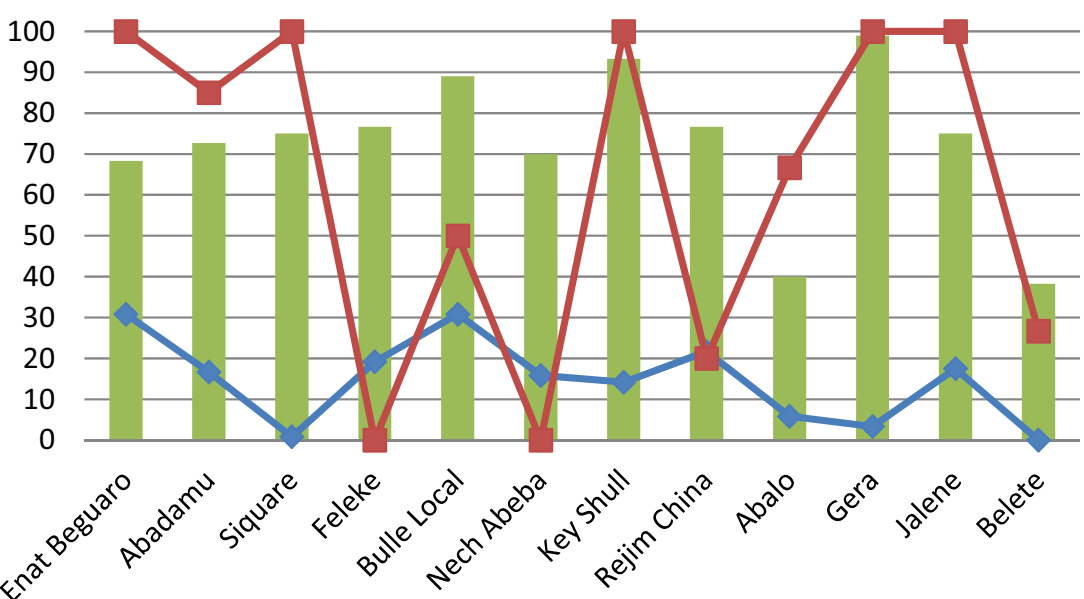

Hail damage (\% of leaf defolation)

$\sim$ Late blight (\% Severity)

Lodging due to wind (\%) 
and Elings 2001). Nonetheless, the relative importance of some of these characters differed between districts and gender groups. Apart from yield and late blight resistance, long shelf life, suitability for boiling (good taste), stew quality (remains firm when cooked and better absorption of fat/oil from the stew) and drought tolerance are important selection criteria for both districts and gender groups; these factors undoubtedly influence the acceptance of new varieties. While farmers consume potatoes both boiled (cooked potato used before cooling down, nothing added) and in stew (known as "Wot"), urban dwellers primarily consume potato as a stew mixed with vegetables (known as "Alicha"). For stew preparation, potato is cut into pieces before cooking; these pieces are then mixed with vegetables and spices and cooked with oil. For boiled potato, the tuber is cooked whole without any spices added.

A previous study showed that early maturity, tuber size and some morphological characters are important variety selection criteria for farmers in Bolivia (Thiele et al. 1997). Early maturity for Meher season production is currently a high priority trait for Ethiopian potato variety developers. However, our study shows that approximately $40 \%$ of farmers did not consider early maturity as a "very important" trait in the Belmehr season as they can adjust the varieties they grow each year depending on when the rain starts. In some years where the rainfall starts early in the Belmehr season, late maturing varieties like 'Abalo' perform well, otherwise early maturing varieties like 'Siquare' are planted to harness the late season rain. By doing this, farmers position themselves to adapt to weather variability and maximize their food security. Thick stems are related to a variety's ability to limit lodging (at Laigaint) and tolerate heavy precipitation including hail (at Yilmana). Similarly, Thiele et al. (1997) indicated that thick stems, plant height, abundant foliage, large tuber size and market related characters are important selection criteria for farmers. We found that tolerance to bird damage was important to farmers in Laigaint as birds are a common problem during planting and after vines have matured (tubers are left unharvested for up to 6 months), and hence varieties with long stolons are preferred.

In both districts farmers prefer varieties that store well for two reasons. First, farmers depend on potato as their primary food source for more than 7 months. These potatoes are typically stored in their homes and kept in darkness. Second, farmers generally use seed from one Belmehr crop for the next Belmehr season; hence tubers need to be stored in situ (infield) and/or in storage structures for at least 7 months. These practices require long shelf life as a varietal trait, and this will influence acceptance of varieties in these two locations.

The importance of quality traits such as storability, taste and other uses are generally overlooked in current variety development efforts in Ethiopia. Tripp et al. (1997) described how traits such as cooking quality, taste, market acceptability and storability are not considered in variety release by public institutions. One of the conclusions of our study is that the variety requirements of resource poor farmers are more diverse than breeders' perceptions, a view shared by several other investigators (Mulatu and Zelleke 2002; Morris and Bellon 2004; Vom Brocke et al. 2010).

Our study further shows the existence of variety selection criteria that vary by agroecological and gender groups. Differences in farmer selection concerns between the two districts are a function of agroecological differences and access to market outlets. Since Laigaint represents a sub-moist (dry) agroecology and is food insecure, the most important variety traits are drought tolerance and suitability to sequential harvesting (including related traits such as long stolons). Farmers' preference for varieties suitable for soil with poor fertility is also related to drought since under conditions of low soil moisture, chemical fertilizers are more difficult for plant roots to access. Farmers in Yilmana are economically better off than their counterparts in Laigaint, and they are thus more concerned with market traits including stew quality. Differences were also clearly observed between gender groups in Laigaint, as women were more concerned with the trait of long stolons (related to sequential harvesting which provides food over a longer period of time) while the men were more concerned with low soil fertility and market traits.

The large number of variety traits important to farmers of both genders in both agroecological zones suggests a need for a diverse set of varieties because it is impossible to find all of these traits in a single variety. Farmers grow multiple varieties to obtain a range of variety traits at the same time; more than 77 and $22 \%$ of the farmers at Yilmana and Laigaint, respectively, grew two or more varieties in the same season (our study). Mulatu and Zelleke (2002) found similar results in their study on highland maize in Ethiopia. The potato varieties from southern Ethiopia (SNNP and Oromia) do not fit the farming system of the two northwestern agroecological zones mainly because of short storability and susceptibility to late blight. Two local varieties ('Abalo' and 'Siquare') and one improved variety ('Belete') have more preferred traits than the other varieties evaluated. 'Abalo', despite its drawbacks such as late blight susceptibility, late maturity for Meher season production, and poor tubers for market purpose, fits well for Belmehr season production due to its long shelf life, suitability for sequential harvesting, excellent taste after boiling and good stew quality. However, the production of 'Abalo' in the Yilmana district has dramatically decreased within the last 3 years because of a shift in rainfall from March to May and an increase in late blight disease pressure. 'Siquare', another variety dominant in northwest Ethiopia is now replacing 'Abalo' in Yilmana because of its relatively good resistance to late blight, good market acceptance and suitability for late planting. This variety, however, is not accepted as a boiling potato in Laigaint, not useful for French fry making in the cities, and not tolerant of strong wind because of its thin stem and delicate leaves. 'Belete' is preferred by farmers for its high yield, 
good late blight resistance and better stew quality, and has better tolerance to some major abiotic stresses such as desiccating wind and severe precipitation; this is likely due to its strong stems and thick leaves. Our agronomic data also revealed that 'Belete' has very good yield stability across districts and seasons. However, this variety is not valued by farmers because it does not store well.

\section{Conclusions}

Potato is one of the few crops in Ethiopia that matures during the months of July and August and thus has an important role in alleviating hunger. Belmehr season production is what most farmers employ to fill their food gaps. Existing new varieties do not provide an effective solution to farmers for production during Belmehr because of poor storability and their generally poor performance in the Belmehr season. Expanding Ethiopian variety development efforts to include Belmehr season production is of paramount importance. Apart from yield and late blight resistance, developing varieties suitable for long storage and sequential harvesting together with better boiling and stew quality needs to be given high priority. The study further shows that several local varieties, such as 'Abadamu', 'Nech Abeba', 'Rejim China' and others yielded as well or better than new varieties in both seasons using disease tested seed. This finding negates the belief that Ethiopian local varieties are low yielding. Importantly, farmers' local varieties can serve as valuable resources for future variety improvement, as they have the necessary qualities and are well adapted to the farming systems of the two agroecological zones. Spraying local varieties for late blight control at least once, promoting use of non-chemical fertilizers such as compost and animal manure, and applying chemical fertilizers (especially potassium) may increase potato productivity in the Belmehr season. New varieties are already playing an important role in complementing existing local varieties during the Meher season production and can be used for immediate consumption as well as for markets. About 47 and $35 \%$ of the participating farmers at Yilmana and Laigaint, respectively, currently grow new varieties, primarily 'Belete' (current study). Introducing additional varieties with good shelf life may also help farmers who grow potato during the Meher season.

This study together with our previously published work (Kolech et al. 2015) helps us understand farmers' variety needs and farmers' production practices as they relate to variety selection. Moreover, these studies help us catalog attributes of local varieties for future use and conservation. Therefore, these studies are the first step for fulfilment of our general objective of developing potato varieties that are well suited to the needs of growers and consumers and that also increase potato productivity. This study further shows that the PVS approach is helpful in understanding the relative importance of farmers concerns in variety selection.

This case study is based on two major agroecological zones that nevertheless employ the same cropping system in northwest Ethiopia (Amhara region). The results of this study can be applied to similar agroecologies and cropping systems in northwest Ethiopia. Since Southern Ethiopia has a different cropping system and grows different varieties than the northwest, a similar study needs to be conducted in that region. Similar studies could also be conducted in central and Eastern highland areas to understand farmers' variety needs and assess the local potato genetic resources located there.

Acknowledgments This work was supported by the Cornell Assistantship for Sub-Saharan Africa in Horticulture (CAHA) and a Richard Bradfield Award from Cornell University. The authors gratefully acknowledge the farmers and development agents who participated in this study. We would like to thank Fentanesh Sendekie, Zewudu and Yeshwas, Wubet Awoke, Mamaru Yeshabel and Alemu Worku from the Adet Agricultural Research Center and Kassahun from Agriculture Development Office at Laigaint for their help with the field work. The generous support of International Potato Center (Ethiopian office) for the support in soil analysis was greatly appreciated.

Open Access This article is distributed under the terms of the Creative Commons Attribution 4.0 International License (http:// creativecommons.org/licenses/by/4.0/), which permits unrestricted use, distribution, and reproduction in any medium, provided you give appropriate credit to the original author(s) and the source, provide a link to the Creative Commons license, and indicate if changes were made.

\section{References}

Abebe, G.K., J. Bijman, S. Pascucci, and S. Omta. 2013. Adoption of improved potato varieties in Ethiopia: the role of agricultural knowledge and innovation system and smallholder farmers' quality assessment. Agricultural Systems 122: 22-32.

Africa Rice Center (AfricaRice). 2010. Participatory varietal selection of rice. The Technician's Manual. Cotonou, Benin. 120 pp.

Agajie, T., K. Bedane, C. Yirga, and G. Woldegiorgis. 2008. Potato socioeconomics and technology transfer. In Root and tuber crops: The untapped resources, ed. W. Gebremedhin, G. Endale, and L. Berga. Addis Ababa: Ethiopian Institute of Agricultural Research.

Almekinders, C.J.M., and A. Elings. 2001. Collaboration of farmers and breeders: participatory crop improvement in perspective. Euphytica 122: 425-438.

Bekele, K., and B. Eshetu. 2008. Potato disease management. In Root and tuber crops: The untapped resources, eds. Woldegiorgis, W., Gebre, E., and Lemaga, B. Ethiopian Institute of Agricultural Research.

Bellon, M.R. 2002. Analysis of the demand for characteristics by wealth and gender: A case study from Oaxaca, Mexico. In Quantitative analysis of data from participatory methods in plant breeding, ed. M.R. Bellon and J. Reeves, 66-81. Mexico: CYMMYT.

Brady, N.C., and R.R. Weil. 2002. The nature and properties of soil, 13th ed. New Jersey: Prentice Hall.

CSA (Central Statistics Agency). 2014. Agriculture sample survey 2013/ 14 (2006 EC): Report on area, production and farm management practice of Belg season crops for private peasant holdings. Volume V: Statistical Bulletin 532, Addis Ababa, Ethiopia. 
Danial, D., J. Parleviliet, C. Almekinders, and G. Thiele. 2007. Farmers' participation and breeding for durable disease resistance in the Andean region. Euphytica 153: 385-396.

Gebremedhin, W. 2013. Potato variety development strategies and methodologies in Ethiopia. In: Seed potato tuber production and dissemination: experiences, challenges and prospects. Proceedings of the National Workshop on Seed Potato Tuber Production and Dissemination. EIAR and ARARI. 12-14 March 2012, Bahir Dar, Ethiopia.

Gebremedhin, W., E. Gebre, and B. Lemaga. 2008. Potato variety development. In Root and tuber crops: Untapped resources, ed. W. Gebremedhin, G. Endale, and L. Berga. Addis Ababa: Ethiopian Institute of Agricultural Research.

Genstat. 2013. Genstat for windows, 6th ed. VSN International LTD, Hemel, Hempstead.

Gibson, R.W., E. Byamukama, I. Mpembe, J. Kayongo, and R.O.M. Mwanga. 2008. Working with farmer groups in Uganda to develop new sweet potato cultivars: decentralization and building on traditional approaches. Euphytica 159: 217-228.

Gildemacher, P., W. Kaguongo, O. Ortiz, A. Tesfaye, G. Woldegiorgis, W.W. Wagoire, R. Kakuhenzire, P.M. Kinyae, M. Wagoire, P.C. Struik, and C. Leeuwis. 2009a. Improving potato production in Kenya, Uganda and Ethiopia: a system diagnosis. Potato Research 52: 173-205.

Gildemacher, P., P. Demo, I. Barker, W. Kaguongo, W. Gebremedhin, W.W. Wagoire, M. Wakahiu, C. Leeuwis, and P.C. Struik. 2009b. A description of seed potato systems in Kenya, Uganda and Ethiopia. American Journal of Potato Research 86: 373-382.

Hirpa, A., M.P.M. Meuwissen, A. Tesfaye, W.J.M. Lommen, A.G.J.M. OudeLansink, A. Tsegaye, and P.C. Struick. 2010. Analysis of seed potato systems in Ethiopia. American Journal of Potato Research 87: 537-552.

JMP. JMP pro 10.0.02. SAS Institute, INC. Cary, NC. 2012

Kidane-Mariam, H. 1980. Project proposal for the development of an Ethiopian potato program manuscript. Addis Ababa, Ethiopia.

Kolech, S.A., D. Halseth, W. De Jong, K. Perry, D. Wolfe, F.M. Tiruneh, and S. Schulz. 2015. Potato variety diversity, determinants and implications for potato breeding strategy in Ethiopia. American Journal of Potato Research 92: 551-566.

Lemaga, B. 1983. Country program report on Ethiopian potato research activities. Presented at the Regional Workshop on Potato Development and Transfer of Technologies in Tropical Africa. Addis Ababa, Ethiopia, 22 August to 1 September 1982.

MOA (Ministry of Agriculture). 2013. Variety register booklet for 2013. Addis Ababa, Ethiopia.

Morris, M.L., and M.R. Bellon. 2004. Participatory plant breeding research: opportunities and challenges for the international crop improvement system. Euphytica 136: 21-35.
Mulatu, E., and H. Zelleke. 2002. Farmers' highland maize (Zea mays L.) selection criteria: implications for maize breeding for the Harerghe highland of eastern Ethiopia. Euphytica 127: 11-30.

Murphy, H.F., 1968. A report on fertility status and other data on some soils of Ethiopia. Experimental Station Bulletin No. 44. Hailesilassie College of Agriculture, Oklahoma State University.

Tesfaye, A., Y. Dessalegn, and E. Abate. 2008. Crop management research and achievement on potato in Amhara Region with special reference to Western Amhara. In Participatory potato technology development and transfer: towards food security and improved livelihoods in the new Millennium. Proceedings of the 1st Amhara region regional workshop on potato research and development: achievements and transfer experiences and future directions. December 20-21, 2007, ed. A. Tesfaye. Bahir Dar: Amhara Agricultural Research Institute.

Thiele, G., G. Gardner, R. Torrez, and J. Gabriel. 1997. Farmer involvement in selection of new varieties: potatoes in Bolivia. Experimental Agriculture 33: 1-16.

Tripp, R., N. Louwaars, W.J. Van Der Burg, D.S. Virk and J.R. Witcombe. 1997. Alternatives for seed regulatory reform: An analysis of variety testing, variety regulation and seed quality control. Agricultural Research and Extension Network. Paper No. 69. Overseas Development Institute (ODI), London.

Umar, S. and Moinuddin. 2001. The effect of sources and rates of potassium application on potato yield and economic returns. Better Crop International 15: 13-15.

Vom Brocke, K., G. Trouche, E. Weltzien, C.P. Barro-Kondombo, E. Goze, and J. Chantereau. 2010. Participatory variety development for sorghum in Burkina Faso: farmers' selection and farmers' criteria. Field Crops Research 119: 183-194.

Wakijira, A., G. Keneni, M. Jarso, and B. Weyessa. 2008. Opportunities for participatory crop improvement and supporting informal seed supply in Oromia region, Ethiopia. In Farmers, seeds and varieties: Supporting informal seed supply in Ethiopia, ed. M.H. Thijssen, Z. Bishaw, A. Bashir, and W.S. de Boef. Wageningen: Wageningen International.

Weltzien, E., M.E. Smith, L.S. Meitzner, and L. Sperling. 2000. Technical and institutional issues in Participatory plant breeding from the perspective of formal plant breeding. An analysis of issues, results, and current experience. CGIAR System wide Program on Participatory Research and Gender Analysis for Technology Development and Institutional Innovation Working Document 3.

Yazie, C., T. Akal, T. Yalfal, and B. Baye. 2009. Characterization of potato production, marketing, and utilization in northwestern Amhara Region, Ethiopia. Working paper. Bahir Dar: Adet Agricultural Research Center. 41 pp. 